\title{
Pattern Principals Leadership in Increasing Quality Education MA Muhammadiyah 10 Palirangan Solokuro Lamongan
}

\author{
Husnul Aqib ${ }^{1)}$, \\ Nur Efendi ${ }^{2)}$ \\ Master of Islamic Education Management, \\ Universitas Muhammadiyah Sidoarjo, Indonesia \\ 1)aqibdjai@gmail.com, \\ ${ }^{2)}$ nurefendi17@ymail.com
}

\begin{abstract}
The leadership pattern of the head a madrasah is very influential in improving the quality of education in an educational institution. This research was conducted at the ma muhammadiyah lamongan 10 palirangan solokuro formulation with the following problems: (1) what is the pattern of leadership of the madrasa heads in improving the quality of education at ma muhammadiyah 10 palirangan solokuro lamongan?; (2) what is the achievement of quality education at ma muhammadiyah 10 palirangan solokuro lamongan?; (3) what are the supporting factors and obstacles to the pattern of leadership of the madrasa leaders in improving the quality of education at ma muhammadiyah lamongan 10 palirangan solokuro ?. The method used in this study uses a qualitative approach to the type of phenomenological research and collection of data through observation techniques, interviews, documentation and questionnaires. As for the results of this study is the leadership pattern of the head of the madrassa by using an autocratic pattern has succeeded in improving the quality of education.
\end{abstract}

Keywords: Leadership, quality, education.

\section{INTRODUCTION}

Humans are social creatures, or commonly referred to as zoon politicon, that creature who can not live alone, always dependent and in need of another person or the surrounding environment. In human life can not be separated from the gregarious or set up an organization, organizational goal is to make it easier to achieve a goal. In the human group or organization needs a leader. Leaders on duty as a regulator, steering, and the waiter members of the group. This is in accordance with the words of the Prophet Muhammad;

$$
\text { مكحأ اورمؤيلف رفس يف ثثلاث نالك اذا .م.ص الله لوسر لاق بلاق هنع الله يضر ةريره بيأنع }
$$

From Abu Hurairah RA. Said that the Messenger of Allah said: "If out of three people on a journey, should one of them be a leader". ( HR. Abu Dawud)

In the hadith of the Prophet Muhammad's leadership term called " ra'in " which also means the management and leaders. Term - the term gives the sense that leadership is guided activities, guide and show the path to the destination blessed God Almighty.

Rasulullah SAW said:

عار لجر لاو ,عار ريملأو ,هتيعر نع لوئسم مكلكو عار مكلك :لاق ملسو هيلع الله لل يبنلا نع امهنع الله يضر رمع نب نعو )هيلع ققتم (هتيعر نع لوئسم مكلكو عار مكاكف

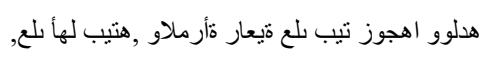

From Ibn Umar. Of the Prophet, he said: "You are a leader and you will be held accountable for your leadership. A ruler is a leader, a husband was a leader of the whole family, as well as a wife is the leader on the home 
her husband and children. You are the leaders who will be held accountable for your leadership ". (HR. Bukhari and Muslim)

In an educational institution both the school and madrasah leader has a very important role. The success of an organization depends on its leaders in this case the principal / madrasah. Then the principal must have the ability and experience better than with teachers and other staff. Because the principal is the top leader then it should be a good example and clever mix and administer educational institutions well.

The principal in developed countries have many names. According Marno \& Triyo Supriyatno quote Ariffin, said that the principal called the teacher's head (head teacher or head master), headmaster (principal), the principal teaching (teaching principal), the principal pensupervisi (supervising principal), director (director), administrator (administrator), the leader of education (educational leadership), Differences in the mention of this, according to the quoted Mantja Marno \& Triyo Supriyatno, due to the criteria that requires professional competence kepalasekolah. As an administrator, the principal is required to utilize the available resources to the maximum. As a manager, the principal must be able to cooperate with others in the organization of the school. As educational leaders, school principals must be able to coordinate and mobilize the potential of subordinates to achieve educational goals. As a supervisor, the principal should be able to help teachers increase student capacity to membelajarkan optimally.

The school principal has the same duties as a teacher. As noted by Winarno Surahmad4 that teachers can be categorized as a group of specialized man power, because they were assigned to live and grounded in the realities of tomorrow. They are responsible for connecting the world (the present world and the world of tomorrow) so that students can discover the benefits of the next day. This expression implies that the principal task is not light. Because the principal as a driving force of a generation, planners, implementers, managers and responsible for his duties as principal.

Of research relating to the principal, then the outline of each educational unit principal has the following duties:

1. Applying management functions by means of implementing formal education for a certain period appropriate types and levels of certain

2. Implementing the curriculum development together with a team of curriculum developers, implementing learning technologies that exist for the realization of the desired quality of education

3. Conducting technical guidance and counseling to improve the quality of learning and teaching methods are creative and innovative.

4. Conducting the coaching and guidance of student activities

5. Assist and supervise the activities ketata usahaan, admisitrasi and other school activities

6. Establish a good cooperation between the guardians of students, the community and other school communities

7. Provide accountability reports to the relevant parties such as governments and stakeholders.

On this basis it is very important that we pay attention to patterns of school leadership / madrasah in educational institutions, both public and private. Because if the principal / madrassas have the skills and the quality was good in managing the school / madrasah then the quality and the quality of school / madrasah can be achieved. So in every educational institution must have the principal has a different leadership patterns vary according to the institution's internal conditions.

MA Muhammadiyah 10 Palirangan Solokuro Lamongan is one Islamic institution / madrasah were very concerned about the quality and the quality of education in order to materialize out put a good education, then the leadership pattern headmaster is of considerable concern because it is very important in determining the direction of the program and policies of the madrasah, this is due to a good enough work ethic of teachers and education staff but the quality of teachers and inadequate both the cognitive and psychomotor although already held various guidance and training and teacher workshops.

This is what makes the author feel interested in conducting research in MA Muhammadiyah 10 Palirangan Solokuro Lamongan.

\section{METHOD}

In this study the author uses descriptive analytical method, its research that revealed the circumstances, occurrences and events ongoing in nature (natural setting) in a location that will be examined, namely at MA Muhammadiyah Lamongan 05 Palirangan Solokuro.

This study will be conducted in MA Muhammadiyah 10 Palirangan Solokuro Lamongan, which is located on Jl. Mosque Nurul Iman Palirangan nomor 80 Village Payaman Solokuro Subdistrict of Lamongan, East Java. 
As a study conducted in MA Muhammadiyah 10 Palirangan Solokuro Lamongan is for 3 months, from January to March 2018. A study certainly needed their types and sources of data so that the research can be accounted for. As in this study using the types and sources of data as follows:

\section{a.Primary data}

Primary data is data obtained directly from the source, ie from the respondents to be studied. Because the data is not contained in the archives or documentation, the investigator must interact with respondents who made the object of the study.

\section{b.Secondary Data.}

Secondary data is the data source that does not directly provide the data to the data collector, This secondary data is the data that are supporting the primary data purposes such as books, literature and related readings.

Data collection techniques used in this study are Observation / Observation ( Observation ). This method researchers use to obtain information and data related to the object of study, the state of infrastructure and supporting facilities state of the learning process. In-depth interviews (In depth interview)

To get sufficient data related to the pattern of leadership headmaster in improving the quality of education, researchers will make use of in-depth interviews with stakeholders, both headmaster, teachers and education staff, school committee and other stakeholders at MA Muhammadiyah 10 Palirangan Solokuro Lamongan. Documentation (Documentation). Documentation method which is a technique to find data collecting existing data such as notes, books, transcripts, newspaper, magazine, agenda, minutes of meetings, legger, and so forth. Questionnaire / quitionary

The questionnaire method is a technique of collecting data through forms that contain the questions submitted in writing to a person or group of people to get answers or responses as a source of information that is needed by researchers. This method is used by researchers to make the data more robust and reliable. This method is used by spreading to the correspondent composed of teachers, staff and committee or existing stakeholders in the research object.

\section{RESULT}

To determine the pattern of leadership that is applied at MAM 10 Palirangan Solokuro Lamongan, these authors describe the results of interviews and questionnaire results were authors spread the head teacher, staff and stakeholders in the MAM 10 Palirangan Solokuro Lamongan.

Interviews the authors obtained from Lukman Hakim as a teacher at MAM 10 Palirangan Solokuro Lamongan he said:

"Head of the MA Muhammadiyah 10 Palirangan Solokuro at MAM 10 Palirangan rarely ask the opinion of a teacher or other staff in every take policy".

Based on the results of these interviews can be concluded that the pattern of leadership MAM 10 Palirangan tend otokratif. This is also reinforced by the results of a questionnaire author to distribute to teachers and staff that results in value 4.15 (Category Good).

According to Lukman Hakim in terms of leadership MAM 10 Palirangan Solokuro implement strict control and supervision of the maximum of the performance of subordinates, it is done so that the performance of subordinates habit not easily loose and weak. Lukman Hakim statement is also in accordance with the results of a questionnaire obtained a score of 4.45 (both categories).

Something similar is found in the psychologist Andreas Imawanto statement which states that a leader must never relax its tight control over their subordinates because without a strong control will establish poor work habits.

In line with the statement Rofiq Ainur as an English teacher said:

"Related to the leadership of MA Muhammadiyah 10 Palirangan Solokuro tend to be more happy finish the job himself for the sake of effective and time efficiency".

The statement is in accordance with the results of a questionnaire which scored 4.50 (both categories). The pattern of this kind of leadership that is applied by the head of MAM 10 Palirangan by Ainur Rofiq not be a problem considering that not all decisions have to be discussed to subordinates because not all subordinates have good managerial abilities. It sesuasi with Anton statement [1] states that one of the advantages pattern autocratic leadership is a decision could be taken quickly because the absolute right of a leader, there is no denial of a subordinate especially weak in managerial subordinates.

Meanwhile, in the implementation of the control and supervision of the performance and the subordinate tasks according to the results obtained from the interviews that the author Agus Thoha, he said: 
"Head of the MA Muhammadiyah 10 Palirangan Solokuro included very strict in implementing the control and supervision of the performance and duties of subordinates".

As if adapted to the existing poll results reached a value of 4.60 (very good). This is done by the headmaster in an effort to evoke the spirit of the teachers and staff to increase productivity in order to produce a good quality of education.

Meanwhile the issue of a decision-head MAM 10 Palirangan tend to be careful and set such decisions based on personal considerations without deliberation. However, the teachers stay enthusiastic and accept every decision because the decision is deemed detrimental to the public interest and does not pose a problem among subordinates. This is consistent with the results of interviews with the author H. Nafi', chairman of the committee MAM 10 Palirangan. And strengthened by the results of a questionnaire which scored 4.30 (both categories).

Meanwhile the results of interviews that the authors obtained from Habib Mukri one of the teachers at MA Muhammadiyah 10 Palirangan, he said that the Head of MAM 10 Palirangan Solokuro favored by teachers and staff as headmaster own ideas and initiatives of creative and excellent in promoting the madrassa he leads.

This statement is also in accordance with the results of the poll by the informants at MAM 10 Palirangan which has a value of 4.70 (very good) and also in accordance with the opinion of [2] who argued that the requirement as principal in addition must have a diploma in accordance with regulation government, have considerable work experience, have a good personality, expertise and knowledge he must also have good ideas and initiatives for the progress and development of the school.

Schools can be said internal quality is closely associated with the involvement of the school community in totality in it. Quality requires a commitment to customer satisfaction that enables an improvement in the employees, students in doing work with the best.

With regard to quality schools, there are some models (characteristics) grade school proposed by Jerome S. Arcaro (2007) are:

1.Focus on costumer, improve the organization of school education quality must serve the needs of both internal and external costumer. Researchers from the observation and description of the learners, it is known that the service at the MAM 10 Palirangan already well in accordance with the indicator. Officers who serve both the needs of educators, learners and guardians of students are satisfied with the existing services.

\section{Total involvement.}

All components are concerned (the school community and the citizens and the government) should be directly involved in the development of the quality of education.

Based on the interview with the headmaster father researcher Nurul Maliq S. Ag, he said that:

"We as the headmaster had tried as much as possible to bring together the school community and society and the government in this case the supervisor's to become directly involved in the development of the quality of education, so that the quality of education".

So based on these interviews can be said that the MAM 10 Palirangan Solokuro no efforts to improve the quality of education through policy chief madrassas.

\section{Measurement.}

Measurements were performed by means of evaluation, the evaluation is used as a reference in improving the implementation of the quality of education. One part that is often used as a measurement instrument is the value of student achievement.

From the observation and documentation that researchers earn can be said that the achievements of learners MAM 10 Palirangan Solokuro good enough, this can be proved by the results of the evaluation of good replay value end of the semester and the UN quite good value.

\section{Commitment.}

Other matters concerning quality education is a shared commitment to quality culture primary school committees and governments.

Based on observation and documentation that researchers earn can be argued that at MAM 10 Palirangan has awakened commitments which have been woven by the school community, whether it's headmaster, teachers and education staff, learners and the school committee. The commitment aims to develop the quality of education at MAM 10 Palirangan.

5.Sees education as a system.

Such an understanding will eliminate the waste of education and to improve the quality of any educational process. 


\section{Continuous improvement.}

The basic principle of quality is continuous improvement (sustained) This step is done consistently find ways to handle the problem and make the necessary repairs. While external quality school namely with regard to the level of success of a school, according to Hendyat Soetopo (2007), there are some components that relate directly to the success of the quality of schools which includes the properties of the service to the satisfaction of customers which include.

According to the results of interviews the authors obtained from Shohifatu Zahro, he said that the head of the MA Muhammadiyah 10 Palirangan always make creative innovations for the development of madrasas, one of which is a top-down model innovation refers to innovation made by the ministry of education and culture16, This innovation made by the headmaster applied by teachers, for example, is a system of teaching modules that can be implemented by teachers at MAM 10 Palirangan.

In terms of the ability to create innovative MAM head 10 Palirangan Solokuro quite well this is also evidenced by the results of a questionnaire showed a value of 4.45 (both categories).

1.Learners are satisfied with the service madrasas, among others satisfied with the lessons learned, were treated well by educators and leaders, the facilities provided, or learners enjoy madrasah situation.

From the observation that researchers get known that MAM 10 Palirangan provide a good enough service to the students, so that students feel fasting and $n$ yemen in the learning process both in the classroom and outside the classroom.

The results of these observations were confirmed by interviews the researchers did with Ahya Muflihun that state.

"Thank God we were comfortable and satisfied with the way educators teach and headmaster was quite good and varied, so that the lessons easy entry, not boring and monotonous. Similarly, the administration of student services in the field is quite good, there are no constraints or care workers complicate our every need "

2.Parents of students are satisfied with the service or services for their child to the parents, (satisfied as it gets periodic reports on the progress of students and school programs)

Observations of researchers obtained known that the madrasa, especially headmaster always give a good steward to the guardians of students, always establish good communication with the trustee pesetas students through a variety of social media, such as group WA so that each condition and development of learners can be monitored and known by guardians of students.

The results of these observations is strengthened by the statement Nurul Maliq, S.Ag as headmaster stating: "We already do all it can provide the best services to guardians of students, both in terms of providing information related to the programs and reports madrasah development of learners each end semerta. We intertwine intense communication in order to trust or public trust in our institutions, the better".

3.Parties to the user / recipient graduates (universities, industry, public) for receiving graduate satisfied with the quality in line with expectations.

Observations researchers get known that among the many graduates or output in MAM 10 Palirangan largely acceptable to continue studying in various universities in the country, both private and public.

The results of these observations is strengthened by Nurul statement Maliq, S.Ag that:

"The quality of graduates or output MAM 10 Palirangan quite good and not inferior to graduates of other schools, so as to follow the college entrance test both private and public widely accepted. There are some graduates who are admitted to the University Trunojoyo through the Joint Selection Entrance State University (SBMPTN), at Bali's Udayana University, University of Muhammadiyah Malang, Universitas Muhammadiyah Sidoarjo, Gadjah Mada University, etc".

4.Teachers and school employees are satisfied with the service, (a division of labor, the relationship between teacher / employee / management, salary / honorarium, and so on).

From the observation known that teachers and employees at MAM 10 Palirangan satisfied with every type of services that exist in the madrassas. The division of tasks equitable and proportionate by the headmaster made each teacher and staff can carry out the task and role according to its competence. Nothing on each other for each other, a good relationship between the leaders, teachers and employees make every task assigned to be light and can be carried out properly.

The results of the observation is corroborated by the statement Rofiq Ainur, S.Pd which states that: "Interwoven communication teachers and employees at MAM 10 Palirangan already well underway. The division of tasks proportionally by the leadership to make teachers and employees can perform their duties properly". 


\section{CONCLUTION}

The conclusion of this study are as follows:

1. Leadership that was applied by

Head of MA Lamongan Muhammadiyah 10 Palirangan Solokuro show the pattern of autocratic leadership. But nevertheless the leadership pattern included in both categories. This is evidenced by the results of author interviews with informants and the results of a questionnaire or questionnaires that authors disclose to the correspondent composed of teachers, staff and school committee that received scores of 4.35 (both categories).

2. Leadership that was applied by the head of MAM 10 Palirangan Solokuro Lamongan successfully improve the quality of education at MAM 10 Palirangan Solokuro Lamongan. This is evidenced by the following results:

a.Achievement of a fairly good quality of education in accordance with the characteristics of quality schooling, the madrasa has been focused on customer service. Because the quality school that is schools that improve the organization of school education quality must serve the needs of both internal and external costumer

b.All components are concerned (citizens and residents asyarakat schools and government) has been directly involved in the development of the quality of education at MAM 10 Palirangan Solokuro Lamongan.

c.The results obtained learners' achievement is good enough, this is evidenced by the results of the obtained results UNBK average value of 74.9 were categorized as good. This means that the pattern of headmaster leadership in improving the quality of madrasah is fair.

d.The level of satisfaction of the user / recipient graduates (universities, industry, public) good enough for accepting graduates with quality in line with expectations. This is evident by the number of graduates or output MAM 10 Palirangan Solokuro received at several universities, both private and state, including the University of Trunojoyo, UGM, UM Malang, UM Sidoarjo, Udayana University Bali through SMBPTN (Selection of Independent Joint Universities ).

e.The existence of good communication fabric between madrasas with parents of students, so every program and policy of the madrasah is known by guardians of students, so that the confidence level guardians of students getting higher. And also the report on the progress of learners who performed periodically.

\section{Factors influencing the leadership of headmaster}

a. Factors supporting the leadership of headmaster include power (strengths) and opportunities (opportunities)

1). The power possessed MAM 10 Palirangan Solokuro, among others: (a) The educational qualifications headmaster is S-1; (b) The educational qualifications of teachers and staff already S-1 all and there are some that have S-2; (c) The head of the madrasa have a lot of experience in the field of education because it has two periods served as headmaster and also served as chairman K3M (Madrasah Working Group) at the district level; (d) Madrasah already accredited status; (e) The head of the madrasa have coaching agenda educators on a regular basis; (f) Support of teachers and education personnel and guardians of students to programs madrassas; (g) The head of the madrassa was young so that the level of thinking and mobility is high; (h) The head of the madrassa is a figure that assertive, creative and authoritative; (i) Availability of learning resources are sufficient, such as library, Wi-Fi / internet; (j) The school facilitates cooperative educators, educators and learners; $(\mathrm{k})$ The head of the madrasa became the center of all things related to the madrasah, so that if one wants to be asked by teachers, educators and students can immediately drawn to the headmaster; (1) The head of the madrasa, teachers and education staff in one room so as to facilitate coordination; (m) The management is quite good headmaster.

This is evidenced by the planning program at the beginning of each school year conducted by teachers and education personnel under the supervision and evaluation of headmaster (a) The school facilitates cooperative educators, educators and learners; (b) The head of the madrasa became the center of all things related to the madrasah, so that if one wants to be asked by teachers, educators and students can immediately drawn to the headmaster; (c) The head of the madrasa, teachers and education staff in one room so as to facilitate coordination; (d) The management is quite good headmaster. This is evidenced by the planning program at the beginning of each school year conducted by teachers and education personnel under the supervision and evaluation of headmaster (e) The school facilitates cooperative educators, educators and learners; (f) The head of the madrasa became the center of all things related to the madrasah, so that if one wants to be asked by teachers, educators and students can immediately drawn to the headmaster; (g) The head of the madrasah, teachers and education staff in one room so as to facilitate coordination; (h) The management is quite good headmaster. This is evidenced by the planning program at the beginning of each school year conducted by teachers and education personnel under the supervision and evaluation of headmaster educators and students can immediately drawn to the headmaster; (i) The head of the madrasa, teachers and education staff in one room so as to facilitate coordination; ( $j$ ) The management is quite good headmaster. This is evidenced by the planning program at the beginning of each school year conducted by teachers and education personnel under the supervision and evaluation of headmaster educators and students can immediately drawn to the headmaster; (k) The head of the madrasa, teachers and education staff in one room so as to facilitate coordination; (1) The management is quite good headmaster. This is evidenced by the 
planning program at the beginning of each school year conducted by teachers and education personnel under the supervision and evaluation of headmaster

2). Opportunity owned by MAM 10 Palirangan Solokuro among other things: (a) support of the board and the community so well; (b) The friendship forum guardians of students who called IWAMU (Association of Parents) MAM 10 Palirangan Solokuro Lamongan; (c) The existence of a link guide that facilitates education learners communicate with the guardians of students.

b.Factors inhibiting the leadership of headmaster include weakness (weaknes) and threats (threats).

1). Weaknesses owned MAM 10 Palirangan among other things: (a) MAM 10 Palirangan Solokuro is owned Persyarikatan madrasah muhammadiyah twigs, so that funding can fully rely on the BOS and guardians; (b) The headmaster considered less close to his subordinates, so communication is often delayed; (c) headmaster tends to apply the pattern of an autocratic leadership; (d) the majority of teachers and education personnel from outside the village and has the task in another satminkal. ; (e) the majority of the students come from outside the village, so that its activity level less than the maximum; (f) there are 5 educational qualifications educator non-educational or not linear; $(\mathrm{g})$ infrastructure in the form of the building is still not meet; $(\mathrm{h})$ media that is still insufficient; (i) The headmaster too tolerant towards teachers and kepedidikan; arriving late / lack of discipline; (j) The achievement of learners in non-academic fields is still lacking; (k) The scientific work of educators is still lacking; (l) Still the educators were late arriving to madrassas.

2). The threat of headmaster leadership, among others: (a) the number of new schools or madrassas; (b) increasing competition among schools; and (c) promiscuity.

\section{REFERENCES}

1. A. Athoillah, Fundamentals of management. Bandung: Pustaka faithful.

2. Daryanto, Principal As Learning Leaders. Jakarta: Gavamedia. 